\title{
PENGARUH TEKNIK MOTIVATIONAL INTERVIEWING UNTUK MENINGKATKAN EMPATI PADA SISWA KELAS VIII SMPN 11 TARAKAN
}

\author{
Dahlia $^{1}$, Siti Rahmi ${ }^{2}$ \\ Fakultas Keguruan dan Ilmu Pendidikan Universitas Borneo Tarakan \\ Email: dahliabk2019@gmail.com
}

\begin{abstract}
Abstrak
Empati merupakan sebuah perasaan yang dimana seseorang menunjukkan rasa ibanya pada orang lain dan mengerti tentang masalah dan keadaan, serta kemampuan untuk membayangkan diri sendiri di posisi orang lain. Tujuan penelitian ini untuk mengetahui pengaruh teknik motivational interviewing untuk meningkatkan empati pada siswa kelas VIII SMP Negeri 11 Tarakan. Jenis penelitian adalah kuantitatif, dengan pendekatan pre-eksperimental dengan one group pretest-posttest design. Populasi penelitian ini sebanyak 127 siswa dengan sampel 10 siswa. Instrumen yang digunakan skala empati, skala yang telah melalui pengujian validasi dari penilaian Alpha Cronbach dan diperoleh koefisien 0,907 yang menunjukkan tingkat reliability yang tinggi. Analisis data menggunakan statistik deskriptif dan analisis inferensial menggunakan uji wilcoxon program SPSS 22.0 for windows. Adapun hasil penelitian bahwa penggunaan layanan konseling kelompok dengan teknik Motivasional Intervienwing dapat meningkatkan empati pada siswa kelas VIII SMP Negeri 11 Tarakan, hal ini berdasarkan hasil analisis data statistik hasil perhitungan uji wilcoxon, nilai asymp sig $=0,005<\alpha=0,05$ menunjukkan $H^{\circ}$ ditolak artinya ada peningkatan.
\end{abstract}

Kata Kunci : Teknik Motivational Interviewing, Empati Siswa

\section{PENDAHULUAN}

Muhamad Irham (2014) Sekolah merupakan miniatur kecil masyarakat tempat di mana siswa belajar tentang kehidupan belajar untuk membangun diri dan mengasah kemampuan berdasarkan ilmu serta mengembangkan potensi yang dimiliki, agar tujuan tersebut dapat tercapai. Peran guru bimbingan dan konseling penting guna membimbing dan mengarahkan hubungan dan cara berkomunikasi seperti apa yang baik dan tepat digunakan dalam bersosialisasi dan berkomunikasi dalam lingkup sekolah. Sangat penting peran seorang guru bimbingan dan konseling untuk memberikan bimbingan pribadi sosial guna membangun siswa mengenai komunikasi yang baik sangat di butuhkan untuk 
melancarkan proses komunikasi dan belajar siswa di sekolah.

Seiring dengan berjalannya waktu, kepedulian siswa terhadap lingkungannya mulai berkurang. Siswa lebih mementingkan kesenangan untuk diri sendiri tanpa memikirkan lingkungan sekitar. Hal ini yang menyebabkan siswa menjadi makhluk yang individual. Zakiah Daradja (dalam Desmita, 2017) Individu adalah "manusia perserongan yang memiliki pribadi/jiwara sendiri, di mana dengan kekhususan jiwa tersebut menyebabkan individu yang satu berbeda dengan individu yang lain. Ada banyak faktor yang menyebabkan siswa menjadi makhluk individual yang kurang peka dengan lingkungan sekitar, yaitu kurangnya empati terhadap temannya, egoisme, serta kurangnya tolong menolong ini di sebut dengan empati. Hal ini dapat dilihat dari situasi sehari-hari yang dialami, seperti pada saat seseorang membutuhkan bantuan orang lain sebagian orang akan langsung membantu orang yang membutuhkan bantuan tanpa memikirkan diri sendiri, kemudian sebagian orang tidak akan berbuat apa-apa meskipun orang tersebut mampu untuk membantu.

Empati merupakan bagian penting yang digunakan untuk membangun sebuah komunikasi serta hubungan sosial yang positif antar sesama anggota kelompok, dengan adanya empati, orang dapat memberikan sebuah respon yang di harapkan atau dibutuhkan oleh lingkungan sekitarnya. Baron dan Byrne (2005) menyatakan empati sebagai kemampuan menempatkan diri pada posisi orang lain sehingga orang lain seakan-akan menjadi bagian dalam diri orang tersebut. Empati merupakan kemampuan untuk menempatkan diri dalam posisi orang lain dan merasakan apa yang orang lain rasakan dalam situasi tertentu (Papalia, dkk, 2004). Hurlock (2011) yang mengungkapkan bahwa empati adalah kemampuan seseorang untuk mengerti tentang perasaan dan emosi orang lain serta kemampuan untuk membayangkan diri sendiri di posisi orang lain.

Kemampuan untuk empati ini mulai dapat dimiliki seseorang ketika menduduki masa akhir kanak-kanak awal (6 tahun) dengan demikian dapat dikatakan bahwa semua individu memiliki dasar kemampuan untuk dapat berempati, hanya saja berbeda tingkat kedalaman dan cara mengaktualisasikannya. Empati mendorong orang untuk mampu memahami dan melihat permasalahan dan sudut pandang yang sesuai, agar dapat menempatkan diri dan memberikan respon yang sesuai dengan permasalahan tersebut. Dikehidupan sehari-hari, banyak sekali permasalahan yang dihadapi oleh setiap siswa, dan respon yang dibutuhkan juga berbeda-beda. Oleh karena itu empati sangat diperlukan dalam membantu orang lain untuk mendapatkan sebuah rasa nyaman dan tenang dalam menghadapi permasalahan yang dialami. Hubungan sosial pada siswa merupakan salah satu fase penting dimana siswa akan berinteraksi langsung dengan berbagai latar belakang yang berbeda, fase tersebut merupakan kesempatan bagi siswa untuk membangun perilaku tolong menolong 
sebagai bekal untuk menjalani pada lingkup yang lebih luas nantinya.

Berdasarkan penjelasan tersebut, dapat disimpulkan bahwa empati merupakan suatu aktivitas untuk memahami apa yang sedang dipikirkan dan dirasakan orang lain, serta apa yang dipikirkan dan dirasakan oleh yang bersangkutan terhadap kondisi yang sedang di alami orang lain, tanpa yang bersangkutan kehilangan kontrol dirinya. Membangun dan mengerti keadaan tersebut diperlukan adanya kepekaan akan permasalahan yang dialami oleh orang lain. Dengan mengertinya seseorang akan isyarat atau ekspresi yang dimunculkan maka, akan mempermudah orang tersebut untuk memberikan respon yang sesuai.

Melihat kondisi ini, kegiatan layanan BK sangat di perlukan untuk terus memberi solusi, agar siswa-siswi SMP Negeri 11 Tarakan dapat meningkatkan empati dengan teman sebayanya. Supaya layanan BK dapat tercapai dengan baik dan sesuai harapan, maka salah satu upaya untuk meningkatkan empati siswa yaitu dengan cara memberikan layanan BK yang dapat digunakan untuk membantu meningkatkan rasa empati melalui layanan konseling kelompok dengan teknik motivational interviewing (MI). Wibowo (2019) menjelaskan bahwa konseling kelompok adalah proses interpersonal yang dinamis di mana individu-individu dalam rentang penyesuaian normal bekerja sama dengan seorang konselor yang terlatih secara profesional, mengeksplorasi dan perasaan dalam upaya untuk mengubah sikap mereka sehingga dapat menangani masalah perkembangan dengan lebih baik dalam kehidupannya. Konselor berinterakasi dengan konseli dalam bentuk kelompok yang di namis untuk menfasilitasi perkembangan siswa dan atau membantu siswa dalam mengatasi masalah yang dihadapi secara bersama-sama. Dari layanan konseling kelompok, penulis memilih menggunakan teknik motivational interviewing.

Rollnick (dalam Erford 2015)
motivational interviewing yaitu proses yang membantu klien mengembangkan motivasi seseorang yang ada dalam diri untuk berubah dan mencapai tujuan konseling. Dalam permasalahan tersebut teknik ini melibatkan menampilkan kondisi-kondisi rasa empati, kehangatan, ketulusan, dan anggapan positif tanpa syarat dan mengembangkan ikatan terapi yang kuat untuk menangani sikap klien dan membantu klien untuk berubah. Konselor profesional harus menunjukkan sikap menerima klien tanpa syarat dan menggunakan keterampilan mendengarkan reflektif dan aktif untuk memastikan bahwa klien merasa dipahami, dan agar klien juga memahami pikiran, perasaan dan perilakunya sendiri. Membantu menumbuhkan rasa motivasi untuk berubah dan meningkatkan empati pada siswa, dan sangat membantu dalam proses konseling.

Berdasarkan hasil observasi dan wawancara dengan guru BK yang di lakukan pada tanggal 20 Januari 2019 di SMP Negeri 11 Tarakan, diperoleh informasi bahwa ada beberapa siswa yang kurang rasa empati dengan temannya sendiri. Khususnya kelas 7 dan 8 selain 
memiliki permasalahan pada siswa kelas yang suka berkelompok dan membentuk sebuah komunitas sendiri, guru juga mengeluhkan adanya sikap acuh siswa tidak hanya membuat suasana kelas menjadi terpecah, tetapi juga semakin membuat adanya sebuah perbedaan yang mencolok pada siswa. Sikap acuh pada siswa juga berdampak pada kurangnya respon terhadap kebutuhan anggota kelompok lain dalam kelas tersebut.

Respon yang sesuai akan memudahkan siswa untuk menentukan respon atau bantuan seperti apa yang tepat di berikan. Selain itu empati juga berfungsi sebagai cara menghindari kesalahpahaman dalam berkomunikasi. Sebagai contoh, seorang siswa di sekolah sedang tidak enak badan akan tetapi teman satu kelasnya justru mengajaknya bermain di lapangan. Tentu respon tersebut bukanlah respon yang sesuai dengan keadaan tersebut, sehingga empati sangat di perlukan guna menanggulangi permasalahan seperti itu. Saat teman tidak bisa melakukan apa yang diperintahkan oleh guru teman yang lainnya hanya menertawakan, ada siswa yang pendapatnya tidak mau disalahkan (mau menang sendiri), cenderung merasa minder, pendiam serta bersikap acuh dengan temannya yang lainnya. Siswa yang kadang mau membantu teman yang lainnya namun temannya meminta imbalan.

Misalnya ada siswa yang akan pergi ke kantin, ada siswa yang ingin titip sesuatu kepada temannya, ia menerima titipan dari temannya namun dengan imbalan ia harus dibelikan es. Jika memiliki makanan lebih mereka tidak mau saling berbagi. Kemudian ada temannya terjatuh mereka tidak langsung menolong namun mereka menertawakan seolah-olah itu sebuah lelucon. Banyak siswa yang memberikan bantuan dengan pamrih.

\section{METODE PENELITIAN}

Jenis penelitian ini adalah kuantitatif eksperimen yang bertujuan untuk mengkaji perbedaan sebelum dan sesudah diberikan teknik motivational interviewing dalam upaya meningkatkan rasa emapti pada siswa kelas VIII SMP Negeri 11 Tarakan. Sampel dalam penelitian ini sebanyak 10 siswa dari populasi 127 siswa. Teknik pengumpulan data yang digunakan adalah skala dan dokumentasi. Adapun Teknik analisis data yang digunakan dalam penelitian ini adalah analisis statistik deskriptif untuk menggambarkan tentang empati pada siswa sebelum (pretest) dan sesudah (posttest) diberi perlakuan pemberian teknik behaviour contract dan analisis inferensial dengan menggunakan uji Wilcoxon untuk pengujian hipotesis.

\section{HASIL DAN PEMBAHASAN Hasil}

Berdasarkan penelitian ini dilaksanakan di SMPN 11 Tarakan terhadap 10 siswa sebagai subjek. Penelitian yang diawali dengan pretest dan kemudian diakhiri dengan posttest. Pada kelompok eksperimen ini diberikan perlakuan konseling kelompok dengan teknik teknik Motivational Interviewing. Pemberian perlakuan pada kelompok eksperimen menggunakan konseling kelompok dengan 
teknik teknik Motivational Interviewing dimana dalam konseling kelompok ini menggunakan 6 tahapan yaitu : tahap prakonseling, tahap permulaan, tahap transisi, tahap kerja teknik motivational interview, Tahap akhir, Pasca konseling. keenam tahap konseling kelompok ini digunakan untuk membantu meningkatkan empati pada siswa maka diberikan layanan dalam suasana konseling kelompok. berdasarkan hasil perhitungan kategori yang tercantum dalam bab III, maka dapat di maka dapat disajikan hasil pengolahan data dan perhitungan skala komunikasi interpersonal pada siswa sebagai berikut :

Tabel.1 Skor Pre-Test Empati Siswa

\begin{tabular}{cccc}
\hline No & Responden & $\begin{array}{c}\text { Skor } \\
\text { Pre test }\end{array}$ & $\begin{array}{c}\text { Kategor } \\
\text { i }\end{array}$ \\
\hline 1 & HE & 57 & Rendah \\
2 & JE & 63 & Sedang \\
3 & RA & 65 & Sedang \\
4 & SA & 62 & Sedang \\
5 & MZ & 64 & Sedang \\
6 & BF & 58 & Rendah \\
7 & AI & 65 & Sedang \\
8 & HK & 62 & Sedang \\
9 & DR & 65 & Sedang \\
10 & LU & 63 & Sedang \\
\hline
\end{tabular}

Tabel. 2 Skor Post-Test Empati Siswa

$\begin{array}{cccl}\text { No } & \begin{array}{c}\text { Respo } \\ \text { nden }\end{array} & \begin{array}{c}\text { Skor } \\ \text { Post test }\end{array} & \text { Kategori } \\ 1 & \text { HE } & 84 & \text { Tinggi } \\ 2 & \text { JE } & 82 & \text { Tinggi } \\ 3 & \text { RA } & 79 & \text { Tinggi } \\ 4 & \text { SA } & 89 & \text { Sangat Tinggi } \\ 5 & \text { MZ } & 77 & \text { Tinggi } \\ 6 & \text { BF } & 83 & \text { Tinggi } \\ 7 & \text { AI } & 89 & \text { Sangat Tinggi } \\ 8 & \text { HK } & 88 & \text { Sangat Tinggi } \\ 9 & \text { DR } & 87 & \text { Tinggi } \\ 10 & \text { LU } & 85 & \text { Tinggi }\end{array}$

Tabel. 3 Analisis Data Empati pada

Siswa

\begin{tabular}{|l|l|l|c|c|c|}
\hline Kelas & $\begin{array}{c}\text { Nila } \\
\text { i }\end{array}$ & $\begin{array}{c}\text { Sampe } \\
\text { I }\end{array}$ & $\begin{array}{c}\text { Nil } \\
\text { ai } \\
\text { Mi } \\
\text { ni } \\
\text { ma } \\
\mathbf{l}\end{array}$ & $\begin{array}{c}\text { Nil } \\
\text { ai } \\
\text { Ma } \\
\text { ksi } \\
\text { mal }\end{array}$ & $\begin{array}{c}\text { Ra } \\
\text { ta- } \\
\text { rat } \\
\mathbf{a}\end{array}$ \\
\hline $\begin{array}{l}\text { Eksp } \\
\text { erime } \\
\text { n }\end{array}$ & $\begin{array}{l}\text { Pret } \\
\text { est }\end{array}$ & 10 & 55 & 65 & $\begin{array}{l}62 \\
40\end{array}$ \\
\hline & $\begin{array}{l}\text { Post } \\
\text { test }\end{array}$ & 10 & 77 & 89 & $\begin{array}{l}84 \\
3\end{array}$ \\
\hline
\end{tabular}

Berdasarkan tabel 10 dapat dilihat bahwa data sebelum diberikan perlakuan yang terdiri 10 sampel diperoleh rata-rata 62,40 dengan penjabaran 10 siswa tersebut masuk kedalam kategori empati rendah dan empati sedang. 10 siswa masuk kedalam kategori tinggi dan sangat tinggi pada data sesudah diberikan perlakuan diperoleh 84,30 dengan penjabaran 10 siswa masuk dalam kategori tinggi dan sangat tinggi. Berdasarkan antara hasil pretest dan posttest terdapat perbedaan empati pada siswa sebelum dan sesudah diberikan dengan teknik Motivational Interviewing. Berikut diagram perbandingan skor pretest dan posttest skala empati pada siswa.

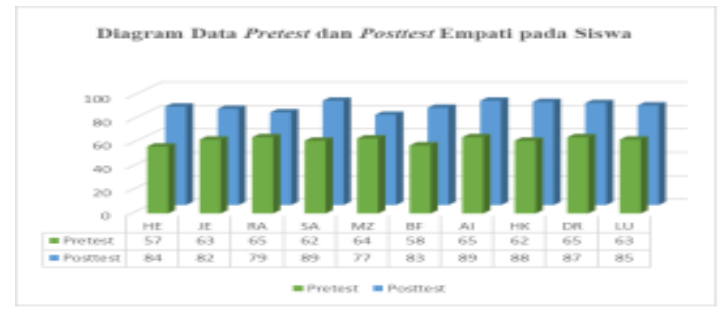

Berdasarkan tabel grafik dapat dilihat adanya peningkatan empati pada siswa dari 
kategori rendah dan sedang menjadi tinggi dan sangat tinggi.

Penganalisaan data menggunakan rumus uji Wilcoxon. Analisis ini termasuk nonparametrik sehingga tidak mengisyaratkan data berdistribusi normal. Analisis ini dapat mengukur data berjenis nominal dan ordinal (Sugiyono, 2015).

Perhitungan uji Wilcoxon pada hasil instrumen sebelum dan sesudah pemberian perlakuan pada penelitian ini menggunakan bantuan perhitungan SPSS 22.0 dengan tarif signifikan 0,05 . Hasil penelitian dapat diperoleh melalui pengujian hipotesis sebagai berikut:

Ha: penggunaan konseling kelompok dengan teknik motivational interviewing dapat meningkatkan empati pada siswa kelas VIII SMP Negeri 11 Tarakan

H0 : penggunaan konseling kelompok dengan teknik motivational interviewing tidak dapat meningkatkan empati pada siswa kelas VIII SMP Negeri 11 Tarakan

Kriteria uji hipotesis penelitian adalah Ha diterima dan $\mathrm{H} 0$ di tolak jika $\mathrm{Z}$ hitung < $\mathrm{Z}$ tabel atau $\mathrm{P}$ value < dari 0,05 artinya teknik motivational interviewing berpengaruh untuk meningkatkan empati pada siswa. Sebaliknya Ha diterima dan $\mathrm{H} 0$ di tolak jika $\mathrm{Z}$ hitung $>\mathrm{Z}$ tabel atau $\mathrm{P}$ value < dari 0,05 artinya teknik motivational interviewing tidak berpengaruh untuk meningkatkan empati pada siswa. Setelah dilakukan pengolahan data dengan menggunakan SPSS 22.0 windows, maka hasil analisis uji Wilcoxon dengan rumus Two Related Samples Test dapat dilihat pada tabel berikut :

Tabel. 4 Hasil Analisis Uji Wilcoxon

\begin{tabular}{|c|c|}
\hline \multicolumn{2}{|c|}{ Test Statistics" } \\
\hline $\mathrm{Z}$ & $-2,807^{\mathrm{b}}$ \\
\hline $\begin{array}{c}\text { Asymp. Sig. (2- } \\
\text { tailed) }\end{array}$ & .005 \\
\hline
\end{tabular}

Berdasarkan tabel 11 diatas, karena nilai asymp sig $=0,005<\alpha=0,05$ maka H0 ditolak yang berarti bahwa ada pengaruh/peningkatan empati pada siswa sebelum dan sesudah diberikan perlakuan teknik motivational interviewing.

\section{Pembahasan}

Berdasarkan hasil penelitian menggunakan konseling kelompok dengan teknik Motivational Interviewing dapat digunakan untuk meningkatkan empati pada siswa kelas VIII SMPN 11 Tarakan. Hasil yang diperoleh dari uji hipotesis menunjukkan bahwa teknik Motivational Interviewing dapat meningkatkan empati siswa yang dilihat dari hasil pretest dan posttest yang meningkat.

Hasil penelitian menunjukkan terdapat peningkatan, terlihat dari hasil pretest sesudah diberikan perlakuan serta di dukung oleh hasil observasi. Hasil penelitian yang dilaksanakan terhadap siswa yang memiliki rasa empati rendah kelas VIII SMPN 11 Tarakan, diperoleh hasil rata-rata skor empati siswa sebelum diberikan perlakuan berada pada kategori rendah yaitu sebesar 62,40 dengan skor nilai terendah 55 dan sedang 65 . Sedangkan rata-rata skor empati sesudah diberikan perlakuan berada pada kategori tinggi yaitu 84,30 dengan skor tinggi 77 dan sangat tinggi 89 . Oleh karna itu dapat 
dikatakan bahwa ada perbedaan empati siswa sebelum dan sesudah diberikan perlakuan berupa teknik Motivational Interviewing.

Hal ini dapat dilihat dari hasil penelitian yang menunjukkan item nomor tujuh yang menyatakan "saya akan menyumbang untuk teman saya yang lagi terkena musibah" termasuk item yang mendapat skor tertinggi di antara item yang lain. Pernyataan pada item tersebut mengarah pada indikator empati "mampu menyesuaikan diri dengan perasaan atau kondisi orang lain" dengan demikian dapat diartikan bahwa kemampuan siswa untuk membantu orang lain mendorong siswa tersebut untuk membuka diri dan memberikan kesempatan kepada temannya untuk menceritakan permasalahan yang dialami, serta siswa tersebut dapat berinteraksi dengan orang lain maka semakin besar pula kemungkinan siswa tersebut untuk melakukan tindakan empati. Pernyataan tersebut sejalan dengan pendapat Schlenker dan Britt (Baron \& Byrne, 2005), individu yang memiliki empati tinggi lebih termotivasi menolong seseorang daripada mereka yang memiliki empati rendah.

Hasil tersebut senada dengan pernyataan Rollnick (2016), yang mengemukakan bahwa pada dasarnya Motivational Interviewing merupakan proses yang membantu klien mengembangkan motivasi interinsik untuk berubah dan mencapai tujuan konseling. Motivational Interviewing juga memiliki empat prinsip yaitu mengekspresikan empati, mengembangkan diskrepansi, menerima resistensi, dan mendukung efikasi diri. Berdasarkan hasil penelitian dan pendapat diatas, tampaknya bahwa penerapan Motivational Interviewing merupakan tindakan yang dapat memotivasikan empati yang kurang yang di alami siswa.

Penggunaan perlakuan dengan menggunakan teknik Motivational Interviewing pada kelompok eksperimen juga membuat respon siswa terhadap pelaksanaan kegiatan layanan konseling kelompok sangat baik, diketahui bahwa respon siswa meningkat dipertemuan pertama hingga pertemuan akhir. Hasil pengamatan menunjukkan pada awalnya siswa kurang terbuka mengenai permasalahan yang dialaminya dan empatinya terhadap teman atau responnya pada temannya sangat kurang, namun setelah siswa memahami tujuan layanan yang diberikan siswa tersebut mulai terbuka. Selama proses pemberian layanan siswa dapat mengikuti setiap tahapan dengan benar dan penuh antusias.

\section{KESIMPULAN}

Berdasarkan hasil penelitian dan pembahasan maka dapat di peroleh kesimpulan bahwa terdapat peningkatan, terlihat dari hasil pretest dan posttest sesudah diberikan perlakuan serta di dukung oleh hasil observasi. Oleh karna itu dapat dikatakan bahwa ada perbedaan empati siswa sebelum dan sesudah diberikan perlakuan berupa teknik Motivational Interviewing. Empati pada siswa kelas VIII SMPN 11 Tarakan masuk dalam kategori tinggi. Terdapat pengaruh positif dan signifikan dari teknik 
Motivational Interviewing terhadap empati siswa kelas VIII SMPN 11 Tarakan. Penggunaan perlakuan dengan menggunakan teknik Motivational Interviewing pada kelompok eksperimen juga. membuat respon siswa terhadap pelaksanaan kegiatan layanan konseling kelompok sangat baik dan mengalami peningkatan.

\section{REFERENSI}

Asmani, J, M. 2009. Jurus-Jurus Belajar Efektif Untuk SMP dan SMA. Jogjakarta: Diva Press

Baron, R.A, \& Byrne, D. 2005. Psikologi Sosial edisi 10. Jakarta: Erlangga

Desmita. 2017. Psikologi Perkembangan Peserta Didik. Bandung: Remaja Rosdakarya.

Erford. 2015. 40 Teknik Yang Harus Di Ketahui Setiap Konselor. Yogyakarta: Pustaka Pelajar.

Fattah, Hanurawan. 2018. Psikologi Sosial Terapan. Depok: RajaGrafindo Persada.

Hurlock, E.B. 2011. Psikologi Perkembangan Suatu Pendekatan Sepanjang Rentang Kehidupan. Jakarta: Erlangga.

Irham Muhamad. 2014 Bimbingan dan Konseling Teori dan Aplikasi di Sekolah Dasar. Depok: Ar-Ruzz Media

Kristianti, Ida Nur. 2014. Meningkatkan Empati Melalui Layanan Bimbingan Kelompok dengan Teknik Sosiodrama Kelas X-2 SMA
Negeri 1 Bringin Tahun Pelajaran 2013/2014. Skripsi. Universitas Kristen Satya Wacana.

Lubis. 2011. Pemahaman dasar-dasar konseling dalam teori dan praktik. Jakarta. Kencana

Prayitno, Amti. 2009. Dasar-Dasar Bimbingan Dan Konseling. Jakarta: Rineka Cipta.

Purnamasari, Iin. 2018. Peran Teknik Motivational Interviewing Dalam Mengatasi Rasa Tidak Percaya Diri Pada Pecandu Narkoba Di Panti Rehabilitasi Narkoba ArRahman. Skiripsi. Universitas Islam Negeri (UIN) Raden Patah Palembang.

Saputra, Tri, Candra. 2016 Pengaruh Empati Terhadap Perilaku Prososial Pada Siswa Kelas XI Kriya Kayu SMKN 1 Pacitan. Skiripsi. Universitas Negeri Yogyakarta. Yogyakarta [Indonesia].

Taufik. 2012. Empati Pendekatan Psikologi Sosial. Jakarta: RajaGrafindo Persada.

Sugiyono. 2015. Metode penelitian pendidikan kuantitatif, kualitatif, dan R\&D. Bandung: Alfabet.

Wibowo, Eddy Mungin. 2019. Konseling Kelompok Perkembangan. Semarang: Unnes Press.

Winkel W.S., \& Sri Hastuti. 2010. Bimbingan Dan Konseling Di Institusi Pendidikan. Yogyakarta: Media 